\title{
TEACHERS' KNOWLEDGE ABOUT HIGHER-ORDER THINKING SKILLS AND ITS LEARNING STRATEGY
}

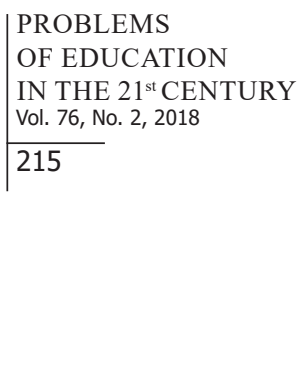

\author{
Heri Retnawati, Hasan Djidu, Kartianom, Ezi Apino, Risqa D. Anazifa \\ Yogyakarta State University, Indonesia \\ E-mail: heri_retnawati@uny.ac.id, hasandjidu@gmail.com, kartianom@gmail.com, \\ apinoezi@gmail.com, rizqa2011@gmail.com
}

\begin{abstract}
Higher order thinking skill (HOTS) is one of the students' abilities that should be developed through teaching and learning. Teachers' knowledge about HOTS and its teaching and learning tactics is a key to successful education. The purpose of this research is to describe teachers' knowledge about higher order thinking skills (HOTS). The research involves qualitative study with the phenomenological approach. The research participants are 27 mathematics teachers from state and private junior high schools across 7 provinces in Indonesia. The researcher collected data with a test followed by focus group discussion (FGD) and interviews. The analysis of data involved Bogdan \& Biklen model and descriptive statistics for data from the test. The analysis of FGD, and test data intends to get information on 6 sub-themes; teachers' knowledge about HOTS, importance of HOTS, teaching about HOTS to students, improving students' HOTS, measuring and assessing HOTS, and teachers'ability for solving HOTS-based problems. The results indicate that teachers' knowledge about HOTS, their ability to improve students' HOTS, solve HOTS-based problems, and measure students' HOTS is still low. There are facts, however, that teachers already understand the importance of HOTS and teaching it by using various innovative learning models. Keywords: HOTS, measurement and assessment, teachers' knowledge, teaching and learning
\end{abstract}

\section{Introduction}

Education is one of the important aspects that can affect national vision. Success in educational implementation is a key to a better future. The latter cannot be achieved without the contribution of various stakeholders. The government, as a policymaker, has the main role and responsibility to pave the way to success, by pledging education for all throughout the nation, for example, education for free policy in developing countries (Quamruzzaman, Rodríguez, Heymann, Kaufman, \& Nandi, 2014). Aside from the government's role, teachers also play an overwhelming role because they put in practice all educational policies and regulations.

Education quality is not only determined by the plan and the development of education but also the quality of its implementation. It also requires supervision of different partners, such as education experts, practitioners, and stakeholders. All of them must synergize to achieve educational success, this means that it not only focuses on the improvement of evaluation, updated curriculum, and new regulations, but also on the development of teaching professionalism (Purnomo, 2017). Some studies revealed that teachers are already a great contribution to improving education quality in many countries (Gil-Flores, Rodríguez-Santero, \& TorresGordillo, 2017; Hu, Fan, Yang, \& Neitzel, 2017; Stylianides, 2007). Therefore, the quality of a teacher to implement educational policy affects the quality of education.

The efforts to improve the quality of education cannot be separated from the demands of 21 st century competitiveness which is complex and challenging. There are three main frameworks of 21st-century skills: 1) learning and innovation skills, 2) life and career skills, and 3) 
Heri RETNAWATI, Hasan DJIDU, KARTIANOM, Ezi APINO, Risqa D. ANAZIFA. Teachers' knowledge about higher-order thinking skills and its learning strategy

OF EDU

IN THE $21^{\text {st }}$ CENTURY Vol. 76, No. 2, 2018

216

information, media, and technology skills (Scott, 2017). Learning and innovation skills consist of communication, collaboration, critical thinking, and creativity skills (4CS). Life and career skills consist of flexibility and adaptability, initiative and self-direction, social and cross-cultural skills, productivity and accountability, leadership, and responsibility. Furthermore, information, media, and technology skills consist of information and media literacy. In addition, Bialik (2015) mentioned four key issues in the 21st-century education implementation framework: Knowledge, skill, character, and metacognition.

Related to the skill, Bialik (2015) and Scott (2017) mentioned that it is relevant to the 4CS competence, which includes creativity, critical thinking, communication, and collaboration. Scott (2017) and Bialik (2015) stated that the 21st-century skills can be grouped into two main components: abstract skills related to thinking skills (creative thinking and critical thinking), and concrete skills (communication and collaboration). Moreover, creative thinking skills and critical thinking skills are included in higher-order thinking skill (HOTS) (Miri, David, \& Uri, 2007; Moseley, Baumfield, Elliott, Gregson, Higgins, \& Newton, 2005).

HOTS is one of the important components for an individual to be able to solve new problems in the 21st century (Brookhart, 2010; Moseley et al., 2005; Thompson, 2008). HOTS also plays an important role in applying, connecting, or manipulating the prior knowledge in order to effectively solve new problems (Thomas \& Thorne, 2009). In the revised Bloom's taxonomy, HOTS is defined as an incision among the three top levels of ability in the cognitive dimension (analyzing, evaluating, creating), and 3 levels of knowledge dimension (conceptual, procedural, metacognitive) (Anderson \& Krathwohl, 2001, Thompson, 2008). Therefore, HOTS is measured using tasks, including analyzing, evaluating, and creating conceptual and procedural knowledge, or metacognition. This means that familiarizing students with HOTS activity is important to help them get ready for solving new issues, acclimatizing themselves in a new atmosphere, and making decisions about a particular problem.

In the implementation of learning, HOTS cannot be directly taught to students. Students should be trained about HOTS, as a skill, through learning activities that support its development. Active learning and student-centered learning are activities for training about HOTS (Akyol \& Garrison, 2011; Limbach \& Waugh, 2010). The active learning and student-centered learning such as problem-based learning (PBL) (Mokhtar, Tarmizi, Job, \& Nawawi, 2013), project-based learning (PjBL) (Vidergor \& Krupnik-Gottlieb, 2015), discovery learning, and inquiry-based learning (Orlich, Harder, Callahan, Trevisan, \& Brown, 2010), or other learning models using contextual problems are some examples of strategies for training students about HOTS. In addition, Protheroe (Goethals, 2013) and Miri, David, and Uri (2007) mentioned that group discussion and solving complex and interdisciplinary problems in the learning process are important activities to train students' HOTS.

The outcome from students' HOTS development can be achieved by the active role of teachers in planning, implementing, and evaluating HOTS-oriented learning. To be able to plan HOTS-oriented learning, teachers need knowledge of ways, strategies, methods to train students about HOTS (Bartell, 2012). Some research results, however, indicate that mathematics teachers face some difficulties, particularly when training their students about HOTS. The obstacles they encounter including difficulty to develop HOTS-based problems and find suited learning tools (Jailani \& Retnawati, 2016; Retnawati, Munadi, Arlinwibowo, Wulandari, \& Sulistyaningsih, 2017; Thompson, 2008), there are also difficulties to evaluate students' HOTS (Retnawati, Hadi, \& Nugraha, 2016). Various obstacles also implicate the low-level of students' HOTS, they mark difficulties when solving mathematics problems in the national exam with contextual problem and narration (Retnawati, Kartowagiran, Arlinwibowo, \& Sulistyaningsih, 2017). 


\section{Research Problem}

Based on the description, it is still needed to conduct the assessment of teachers' knowledge about HOTS and its learning strategies. Throughout this research, it is expected to get a broad picture of teachers' knowledge about HOTS and its learning strategy. This information assists in planning programs that can increase teachers' knowledge about HOTS and its learning strategy. Therefore, this study intends to describe teachers' knowledge about HOTS and its teaching strategy in mathematics classroom.

\section{Researcher's Role}

In this research, the only relationship between the researcher and participants is to collect and explore data with test, focus group discussion (FGD), and interviews resulted from teacher knowledge about HOTS. The next step was to analyze the data for having advanced understanding. The researcher did not undertake any treatment upon the participants in terms of the teacher's knowledge and mathematics teaching and learning strategies implemented by the teachers in the classroom.

\section{Research Methodology}

Research Type

This research is a qualitative study in the phenomenological approach. This research aims to explore teachers' knowledge of HOTS and their teaching strategy in mathematics classroom.

\section{Research Participants}

The research participants were 27 mathematics teachers (14 female against 11 male; T1T27) from 13 private Junior High Schools and 14 state Junior High Schools from 7 provinces in Indonesia. They were randomly selected. All teachers have more than 10 years of experience teaching Mathematics in Junior High School. They haven't participated in training for HOTS and its teaching and learning strategy yet.

\section{Instrument and Procedure}

The teachers passed a test, involved in Focus Group Discussion (FGD) and in-depth interviews so that the researcher could get detailed information. The test consists of 2 constructed response items that adapted from PISA released items. Two mathematics education experts had validated the items. FGD and interviews topics consist of six sub-themes: 1) Teachers' knowledge on HOTS, 2) importance of HOTS, 3) learning strategy in implementing HOTS, 4) improving students' HOTS, 5) measuring and assessing HOTS, and 6) teachers' ability to solve HOTS problems. The test was also administered to measure teachers' HOTS by giving them HOTS problems in Figure 1.

\section{Data Analysis}

Data from FGD and interviews were analyzed and presented in a table to be classified into sub-themes. Analysis of data from the FGD involved Bogdan and Biklen model (1982) in order to know the relationship among sub-themes. On the other hand, the analysis of teachers' answers about solving HOTS problems involved descriptive analysis. 
Heri RETNAWATI, Hasan DJIDU, KARTIANOM, Ezi APINO, Risqa D. ANAZIFA. Teachers' knowledge about higher-order thinking skills and its learning strategy

PROBLEMS

OF EDUCATION

IN THE $21^{\text {st }}$ CENTURY

Vol. 76, No. 2, 2018

218

\section{Ethical Consideration}

At the beginning of the FGD and interviews, the researcher informed the participants that the study would only capture their knowledge about HOTS and its teaching and learning strategy. The FGD and interviews were naturally conducted to obtain credible information. The teachers' names were kept and for the purpose of the research, their identities were coded to ensure their answers have no effect on their professions as teachers.

\begin{tabular}{|c|c|c|c|}
\hline \multicolumn{4}{|c|}{ 1. Magazine Subscription } \\
\hline \multicolumn{3}{|c|}{ Geo-Picture Magazine Category } & Price List \\
\hline \multicolumn{3}{|l|}{ Geo-Picture Indonesia } & Rp50.000,00 \\
\hline \multicolumn{3}{|l|}{ Geo-Picture Traveler } & Rp45.000,00 \\
\hline \multicolumn{2}{|l|}{ Geo-Picture for Kids } & & Rp20.000,00 \\
\hline \multicolumn{4}{|c|}{$\begin{array}{l}\text { The magazine also offers annual subscription packages. If you subscribe at least two magazines in a year, you will get } \\
\text { the discounts which are listed below: }\end{array}$} \\
\hline \multicolumn{3}{|c|}{ Geo-Picture Magazine Category } & \multirow{2}{*}{ Price List } \\
\hline \multirow[t]{5}{*}{ Geo-Picture Indonesia } & Geo-Picture Traveler & Geo-Picture for Kids & \\
\hline & & & Rp600.000,00 \\
\hline & & & Rp600.000,00 \\
\hline & & & Rp444.000,00 \\
\hline & & & Rp804.000,00 \\
\hline \multicolumn{4}{|c|}{$\begin{array}{l}\text { If Rudi wants to subscribe the magazines, which one is the cheapest package that should be choosen by Rudi? } \\
\text { Explain! }\end{array}$} \\
\hline \multicolumn{4}{|c|}{$\begin{array}{l}\text { Two players threw a dice. From the dice number that appears, the larger dice number is reduced by the smaller dice } \\
\text { number. If the difference is } 0,1 \text {, or } 2 \text { then player A gets } 1 \text { point. However, if the difference is } 3,4 \text {, or } 5 \text { then player B } \\
\text { gets } 1 \text { point. The game ends after } 12 \text { dice and the player with the most points is the winner. } \\
\text { Is the game fair? If the game were unfair, how would the rules be changed to make the game fair? }\end{array}$} \\
\hline
\end{tabular}

Figure 1: The test to measure teachers' ability in solving HOTS problems.

\section{Research Results}

Result gives information about teacher's perceptions towards mathematics learning to improve HOTS. The teachers' perceptions are classified into teachers' knowledge on HOTS, its importance, its implementation learning strategy, its improvement in students, its measurement and assessment, and teachers' ability to solve HOTS-based problems. The researcher explained every sub-theme here below.

\section{Teachers' Knowledge about HOTS}

The results out of data analysis and reduction of teachers' knowledge about HOTS show that their knowledge about HOTS is still low. Some explanations given by teachers are general. In fact, there are many teachers who are still confused about distinguishing between HOTS and its strategies or learning methods. The same results can be seen in Table 1. The findings indicate that some teachers have explained HOTS using the three top levels of the revised Bloom's tax- 
Heri RETNAWATI, Hasan DJIDU, KARTIANOM, Ezi APINO, Risqa D. ANAZIFA. Teachers' knowledge about higher-order thinking skills and its learning strategy

onomy (analyzing, evaluating, and creating) while others use critical thinking skill, creativity, problem-solving, logic, reflective, and metacognitive. Based on the FGD result, new teachers are able to understand conceptual knowledge, but cannot explain the operational knowledge properly. Based on teachers' responses, not all teachers understand HOTS well. Teachers still cannot differentiate among abilities, skills, learning methods or learning activities. Although the term HOTS always appears in teacher training activities and socialization of Curriculum 2013, teachers cannot understand its definition.

Table 1. Teachers' knowledge about HOTS definition.

\begin{tabular}{ll}
\hline Definition of HOTS according to mathematics teachers & Verification result \\
\hline Learning stage that requires mastery of the correct concept & $\begin{array}{l}\text { Not all teachers understand } \\
\text { HOTS well. Teachers are still } \\
\text { unable to distinguish HOTS as } \\
\text { an ability, skill, learning strategy, } \\
\text { Thinking skill that is more than just memorizing and reading } \\
\text { High cognitive process, such as analysing, evaluating, and creating } \\
\text { Thinking ability through understanding, observing, exploring, and inferring data }\end{array}$ \\
$\begin{array}{l}\text { Critical thinking skill, creativity, logic, problem-solving, and metacognitive } \\
\text { Learning process which includes knowledge, skill, and analysis }\end{array}$ \\
$\begin{array}{l}\text { High-level problem-solving ability } \\
\text { Problem analysis skills }\end{array}$ \\
$\begin{array}{l}\text { Learning methods which are not just for solving a problem, but understanding it at } \\
\text { a high level }\end{array}$ \\
Ability to solve problems with various ways
\end{tabular}

\section{Teachers' Knowledge about the Importance of HOTS}

Table 2 contains the findings out of data analysis and reduction for teachers' knowledge about HOTS. Teachers' responses to the second sub-theme prove that most of the teachers said that HOTS is important because of its advantages in solving various and complex problems. Therefore, HOTS-oriented learning is very important in learning process as far as it helps solve daily life problems.

Table 2. Teachers' knowledge about the importance of HOTS.

\begin{tabular}{|c|c|}
\hline The importance of HOTS & Verification result \\
\hline $\begin{array}{l}\text { In learning mathematics, students' task is not mastering the concept but also engaging } \\
\text { problem-solving skills }\end{array}$ & \multirow{10}{*}{$\begin{array}{l}\text { Most teachers have realized } \\
\text { the importance of HOTS } \\
\text { for students, i.e. improving } \\
\text { students' skills in solving } \\
\text { daily life problems. }\end{array}$} \\
\hline Training both students' thinking and problem-solving skills & \\
\hline Making a coherent learning process, such as analysing problem and evaluating & \\
\hline Being able to think and carefully solve very difficult problems & \\
\hline Training students in critical thinking & \\
\hline $\begin{array}{l}\text { Not separating HOTS from the cognitive elements of critical thinking skills, creativity, } \\
\text { problem-solving, logic, reflective, and metacognitive }\end{array}$ & \\
\hline $\begin{array}{l}\text { Needing knowledge, skill, and analysis skill in solving problem that might be faced in } \\
\text { daily life }\end{array}$ & \\
\hline HOTS is required to solve problem & \\
\hline Reaching out routine and unexpected problems (non- routine problem) & \\
\hline Studying easily by using HOTS & \\
\hline
\end{tabular}


Heri RETNAWATI, Hasan DJIDU, KARTIANOM, Ezi APINO, Risqa D. ANAZIFA. Teachers' knowledge about higher-order thinking skills and its learning strategy

PROBLEMS

OF EDUCATION

IN THE $21^{\text {st }}$ CENTURY Vol. 76, No. 2, 2018

220

to learn. Based on their responses, some teachers still argue about the importance of HOTS. They stated that HOTS is used to train children to think critically (T5). By teachers' responses, it is worthy to conclude that teachers already know the importance of HOTS. The majority of respondents are aware of the importance of HOTS.

\section{Teachers' Knowledge about Implementing HOTS in Learning Process}

For the third sub-theme, teachers were asked to explain the strategies for teaching HOTS. In the same sub-theme, teachers are expected to describe learning model that can be suited to teaching HOTS in mathematics topics. The results can be seen in Table 3.

Table 3. Teachers' knowledge about implementing HOTS in learning process.

\begin{tabular}{|c|c|}
\hline Ways of implementing HOTS in learning & Verification result \\
\hline $\begin{array}{l}\text { Learning atmosphere should be fun, mastering of basic concepts must be strong, using small } \\
\text { groups, using HOTS questions as a habit, developing perseverance and curious attitude }\end{array}$ & \multirow{10}{*}{$\begin{array}{l}\text { Teachers know that } \\
\text { teaching HOTS can } \\
\text { be done by using vari- } \\
\text { ous learning models. } \\
\text { Teachers are able to } \\
\text { mention a number of } \\
\text { learning models for } \\
\text { teaching HOTS. }\end{array}$} \\
\hline Using problem-solving approach and giving analysis-related questions & \\
\hline Teaching students to analyze, evaluate, and create systematically & \\
\hline $\begin{array}{l}\text { Training students to use complex questions and articulate problems, and asking them to find } \\
\text { an answer by following a particular procedure }\end{array}$ & \\
\hline Providing problems related to their daily problems & \\
\hline Applying problem-solving approach & \\
\hline Giving students problems or HOTS-based questions & \\
\hline Understanding, identifying, determining formulas, and solving problems & \\
\hline Giving PISA questions to students & \\
\hline $\begin{array}{l}\text { Applying problem- based learning, project-based learning, active learning, inquiry learning, } \\
\text { and cooperative learning }\end{array}$ & \\
\hline
\end{tabular}

Results show that teachers' knowledge on teaching HOTS has a positive impact. The teachers believe that training students' HOTS can be done through various learning models. The results also indicate that teachers already know that teaching HOTS to students can be carried out by learning activities containing problem-solving. In addition, teachers' responses proved their knowledge about problem-based learning, project-based learning, active learning, inquiry learning, and cooperative learning.

\section{Teachers' Knowledge about Improving Students' HOTS}

The results about teachers' knowledge on improving students' HOTS can be seen in Table 4. In this sub-theme, teachers were asked to explain learning activities which can improve students' HOTS, the results indicate that they are still unable to explain how to improve students' HOTS, either conceptually or operationally.

Teachers' answers show their misunderstanding about the operational implementation of learning activities to train about HOTS. Most of the answers given by teachers are still normative, such as "asking students to think critically", "Continuously training them about thinking skills", and "training them by asking questions, creating group discussions, giving analysis (C4) or evaluation (C5) related questions". 


\section{Table 4. Teachers' knowledge about improving students' HOTS.}

\begin{tabular}{ll}
\hline Mechanisms to improve students' HOTS & Verification result \\
\hline Learning habit and mentorship & $\begin{array}{l}\text { Most teachers still cannot } \\
\text { explain how to improve } \\
\text { students' HOTS, either } \\
\text { conceptually or operation- } \\
\text { ally. }\end{array}$ \\
$\begin{array}{l}\text { questions } \\
\text { Mraining games followed by increasing the level of thinking }\end{array}$ & \\
Applying problem-based learning model & \\
Designing methods, techniques, or approaches which can improve HOTS & \\
Giving students problems ordered from low to high level & \\
Providing students with problems from easy to difficult level & \\
Assigning students to read more HOTS literature & \\
Reading a lot of reference books and exchanging knowledge, methods, or knowledge \\
with friends
\end{tabular}

Teachers' Knowledge about Measuring and Assessing HOTS

The results from data analysis and reduction are summarized in Table 5. Their responses indicate that most teachers can measure and assess HOTS, by describing, confirming based on observation and presentation, and scoring.

\section{Table 5. Teachers' knowledge about measuring and assessing HOTS.}

\begin{tabular}{|c|c|}
\hline How to measure and assess HOTS & Verification result \\
\hline Conducting interview with some students on the difficulty of HOTS problems & \multirow{10}{*}{$\begin{array}{l}\text { Most teachers already have idea } \\
\text { about appropriate instruments to } \\
\text { assess HOTS, such as essays, } \\
\text { observation of problem-solving } \\
\text { process, confirmation relying on } \\
\text { observation and presentation, anc } \\
\text { scoring system. }\end{array}$} \\
\hline $\begin{array}{l}\text { Measuring students' understanding on solving problems, constructing and find- } \\
\text { ing solutions, and evaluating the outcomes }\end{array}$ & \\
\hline $\begin{array}{l}\text { Observing the effort of students in thinking and solving their problems, by } \\
\text { themselves }\end{array}$ & \\
\hline Analysing students' answers especially in the process of completing the answers & \\
\hline Using written assessment and observation & \\
\hline $\begin{array}{l}\text { Conducting assessment of the process and final evaluation. Developing an } \\
\text { instrument measuring high-level skills }\end{array}$ & \\
\hline $\begin{array}{l}\text { Using essays, assessing the process of finding solutions and stating final solu- } \\
\text { tion, interviewing students or assessing their presentations }\end{array}$ & \\
\hline Giving continuous problems and observing the improvement & \\
\hline Giving essays rooted on students' daily life problems & \\
\hline Using assessment sheet, essay test, and open-ended problems & \\
\hline
\end{tabular}

The results make it clear that teachers already know about different instruments suited to measuring HOTS, such as essays with contextual problems. Other responses explain the techniques for assessing procedures for not appraising the outcome only. These results indicate that teachers already know the instruments used to conceptually measure HOTS. These responses, however, only explain the assessment process regarding problem solving steps, none of them clarifies how to measure or assess HOTS with Bloom's taxonomy. 
Heri RETNAWATI, Hasan DJIDU, KARTIANOM, Ezi APINO, Risqa D. ANAZIFA. Teachers' knowledge about higher-order thinking skills and its learning strategy

OF EDUC

IN THE $21^{\text {st }}$ CENTURY Vol. 76, No. 2, 2018

222

Teachers' Ability for Answering to the HOTS-Based Questions

In this study, the researcher asked teacher to find answers to some problems in order to find out teachers' HOTS. Examples of teachers' answers in solving the first HOTS problem are listed below.

"The cheapest package is the fourth one because if the normal price per annual subscription is calculated, the first package price drops by Rp540.000,00, the second by Rp240.000,00, and the third Rp336.000,00, and the fourth Rp576.000,00" (T1)

"The packages that should be chosen are Geo-Picture Indonesia and GeoPicture Traveler which is only for Rp600.000,00 because the subscription price of each magazine is cheaper than Geo-Picture for Kids" (T2)

"I can choose Geo-Picture Indonesia, Geo-Picture Traveler, and Geo-Picture for Kids for Rp804.000,00 because they have the biggest discount" (T3)

"I can choose 3 books from the first package because if the price is accumulated, it has more discount" (T4)

"I can choose Geo-Picture Indonesia and Geo-Picture Traveler package because the discount is bigger than other packages" (Teacher 5)

From the five answers, the right answer is the answer from Teacher 1, He systematically solved the problem of "Magazine Subscription" and identified important information by analyzing, investigating, solving problems (creating), evaluating and drawing conclusions. The way he solved the problem is presented in Figure 2.

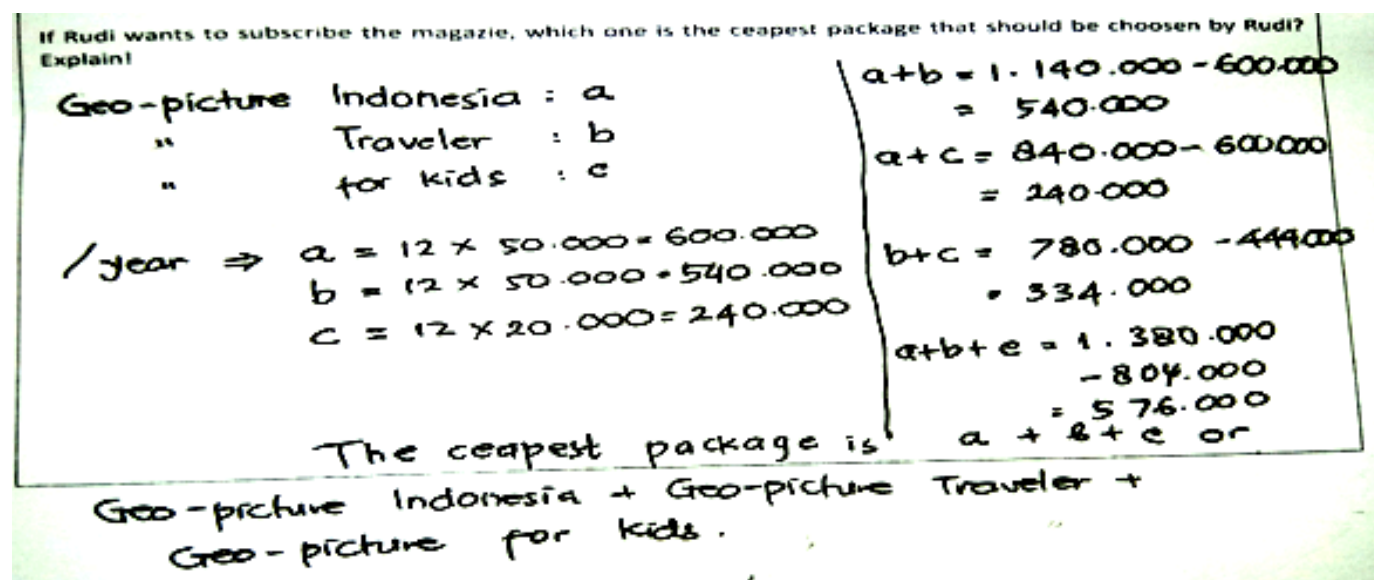

Figure 2: Answer by teacher 1.

Figure 2 is an example of the correct answer. Teacher 1 solved the problem by separating the magazines, determined the price of each magazine within one year, and then the discount for each package. After that, he took the decision by considering the biggest discount. Therefore, according to Teacher 1, the cheapest package that should be chosen by Rudi is the fourth one. Teacher 3 and Teacher 4 actually have the correct answer, but their answers are not built on problem-solving process. Figure 3 contains the work by teacher 3 . 


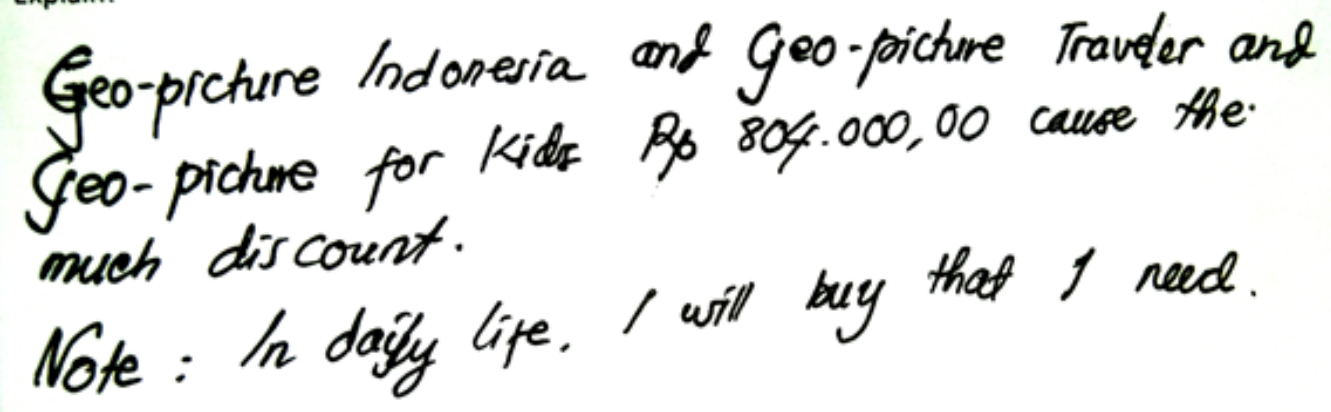

Figure 3: Answer by teacher 3.

Figure 3 is an example of the correct answer but not complete with clear and detailed completion process. It can be seen in Figure 3 that Teacher 3 chose the fourth package because of its discount. The discount referred to by Teacher 2, however, is not included in the process of drawing his conclusion. The way of understanding of teacher 2 is still partial in solving HOTS-based problems. In contrast, Teacher 2 and 5 gave different answers from three other teachers. Teacher 2 selected the second package because he compared prices of all magazines, whereas Teacher 5 preferred the first package because of its price. Figure 4 illustrates the work of Teacher 2 on the problem.

If Rudi wants to subscribe the magazie, which one is the ceapest package that should be choosen by Rudi? Explain!

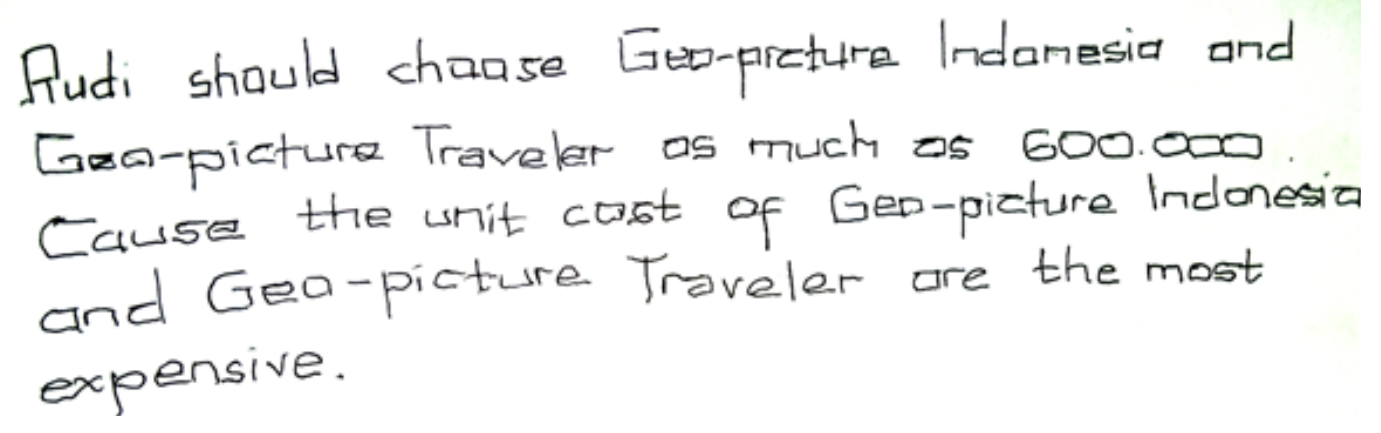

Figure 4: Answer by teacher 2.

Figure 4 is an example of the wrong answer. The mistake of teacher 2 lies within his process of drawing conclusion, the process is not accompanied with a clear completion. Teacher 2 selected the first package (Geo-Picture Indonesia and Geo-Picture Traveler) because the price of each magazine in the package is the most expensive comparing to each price of the GeoPicture Traveler. The reason was given by Teacher 2, however, is not appropriate to answer the question. There are two possibilities that cause teachers to make wrong answers. First, the teacher does not understand the question. Second, the teacher does not understand the discount concept. Therefore, it can be concluded that Teacher 2 skills to solve the HOTS problem are still low.

For the second HOTS-based problem, the teachers' answers vary. The sample of them is listed below. 
Heri RETNAWATI, Hasan DJIDU, KARTIANOM, Ezi APINO, Risqa D. ANAZIFA. Teachers' knowledge about higher-order thinking skills and its learning strategy

OF EDUCATION

IN THE $21^{\text {st }}$ CENTURY

Vol. 76, No. 2, 2018

"In my opinion, the game is fair" ( $\mathrm{T} 7, \mathrm{~T} 9$, without reason)

"A is as probable as $\mathrm{B}, 1 / 2$ " (T15, without mentioning fair or not fair)

"The game is not fair because the probability of A is different from that of B." (T20, T24)

The answers of T7, T9, and T15 are wrong, and the answers of T20 and T24 are partially correct. The correct answer is from T25, Figure 5.

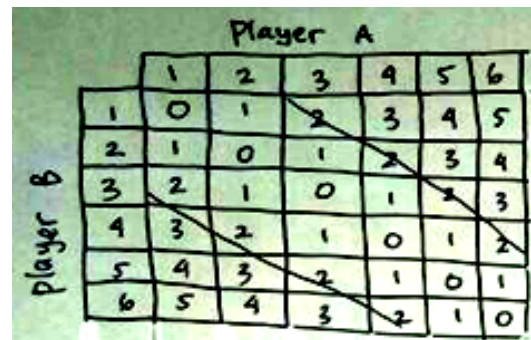

difference $0.1,2 \rightarrow$ A gets 1 poin

difference $3,4,5 \rightarrow B$ gets 1 poin

$P(A)=\frac{24}{36}=\frac{2}{3}$

$P(B)=\frac{12}{36}=1 / 3$

Probability A to get point

more than $B$.

The game is not fair.

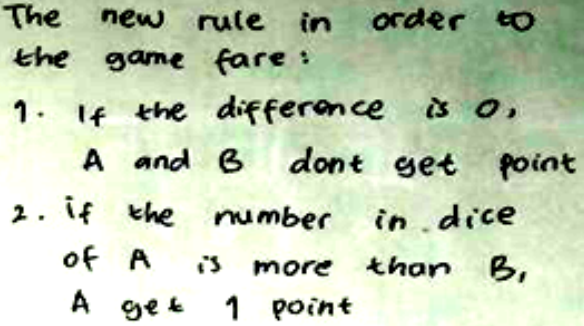

\section{Figure 5: Answer by teacher 25.}

Many teachers have partially made correct answers. They wrote that the game is not fair, but they didn't give the reason behind or propose the new rule to turn the game fair. For example, the T22 answer is illustrated in Figure 6. In this answer, the teacher wrote the analysis to make the new rule but did not write the rule. From the answers of teachers to the test, the teachers' skills to solve HOTS problems in mathematics are still low.

The game is anfair

The rule should be changed:

A. the difference of 2 dices, $2 k 1$ (because $2 \mathrm{can}$ appeare 8 times, $\&$ 1 (an appeare 10 cimes).

B. the difference of 2 dices $5,4,3,0$ Cbecause 0 can appeare 6 ciones

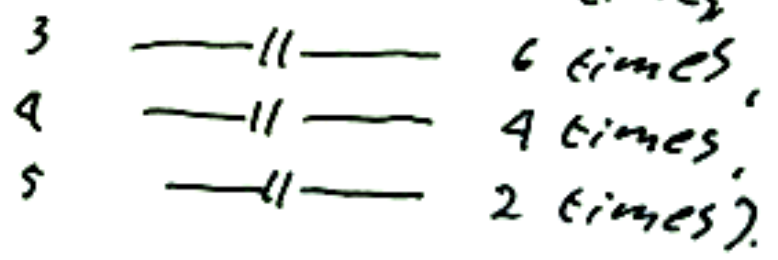

Figure 6: Answer by teacher 22. 
Curriculum 2013 is the latest curriculum that has been implemented in Indonesia since 2013. One of the components of the Curriculum is higher-order thinking skill (HOTS). According to the revised Bloom's taxonomy (Anderson \& Krathwohl, 2001), HOTS is an incision between the three top components of cognitive process dimension (analysis, evaluation, and, creation) with the three top components of knowledge dimension (conceptual, procedural, and metacognitive). Based on the definition, the possibility of teachers to understand the whole concept of HOTS is still lacking. Moreover, teachers will have hugely difficult moments to apply HOTS in learning process, if not accompanied by socialization and training from the government on a regular basis.

The findings of this study indicate that teachers still misunderstand HOTS. Some teachers assume that HOTS is the learning phase (Teacher 1 and Teacher 7). Another teacher also assumes that HOTS is a method of learning (Teacher 10). Considering the fact that some teachers still partially understand HOTS, socialization and training are still needed in order to introduce HOTS to mathematics teachers. The quality of socialization and training is important so that teachers can get more understanding ability and skills about HOTS through these activities. Retnawati (2015) also stated that based on the qualitative study, teachers' trainings and Curriculum 2013 socialization are still insufficient. Some issues are found in teacher training and socialization, such as multiple interpretations in terms of training and socialization themes and time limitations that lead to incomplete delivery of the materials. These issues need to be considered for further training and socialization.

HOTS is one of the important things that become the orientation key of educational policy implementation. There are two main reasons that students have to perform successfully in schools and they should make a positive contribution to the society (Conklin, 2012). Therefore, HOTS is very important to be applied in learning process so that students get ready to contribute to the society. In learning mathematics, HOTS is one of the determinant factors of student success. The complexity of materials and problems in mathematics also requires educators; teachers and students; to have higher-order thinking skills. Both students and teachers should realize the importance of HOTS for students.

The outbreak of HOTS issues in the implementation of learning in Indonesia requires empirical changes. Ahmad (2014) revealed that there are two teacher perceptions about the educational change, positive perceptions and negative perceptions. Positive perceptions cultivate a desire for change and innovation, whereas negative perceptions indicate teachers' unpreparedness to make changes. Both teachers and student are related to the urgency of HOTS. A study conducted by Avargil, Herscovitz, and Dori (2012) found that students also support teacher professional development, and so do the teachers. It can be seen from one teacher's response that HOTS is important "because we encounter some problems that need knowledge, skills, and analysis so that we can fix our daily life problems". In the response, teachers use the word "us" instead of "students" or "them", which means that HOTS is not only needed by students but also by their teachers.

The results show that teachers have realized the importance of HOTS. Teachers' awareness demonstrates that they are ready to make changes or improvements during learning process. Although some previous research (Jailani \& Retnawati, 2016; Retnawati, 2015; Retnawati et al.; 2016; Retnawati, et al., 2017) demonstrated a number of teacher difficulties in implementing learning or assessment model that fits the demands of the Curriculum, the results of this study indicate that teachers believe the importance of implementing HOTS in the learning process. This belief will foster the spirit of teachers in making innovation and change which in line with the positive perceptions of teachers towards the curriculum changes and also foster teachers' desire to innovate in order to support the implementation of the new curriculum (Ahmad, 2014). 
OF EDUC

IN THE $21^{\text {st }}$ CENTURY Vol. 76, No. 2, 2018

226

To realize the importance of HOTS, teachers need to teach the skills to students. Designed learning activities should develop students' HOTS. Some research results indicated that it is necessary to alter traditional learning methods to innovative learning methods for learning HOTS. Those innovative methods are student-centered learning (Sumarmo \& Nishitani, 2010), use of constructivism, and provision of opportunities to students for exploring their abilities during problem-solving activities (Apino \& Retnawati, 2017; Djidu \& Jailani, 2016a). Some models of learning that belong to innovative learning are problem-based learning (Djidu \& Jailani, 2016b), project-based learning (Anazifa, 2017), discovery learning (Rochani, 2016), and creative problem solving (Apino \& Retnawati, 2017).

Results also indicate that most teachers already know that teaching HOTS to students can use various models of learning such as problem-based learning, project-based learning, inquiry learning, and problem-solving. Utilization of HOTS questions with contextual problems or PISA problems was also mentioned by the teachers as one of the appropriate strategies to train for HOTS. Related to the teachers' knowledge on teaching HOTS by using various learning models, they likely have already been trained about implementing Curriculum 2013. In addition, they possibly get information about learning models from teachers' textbooks or other references. However, teachers' knowledge on various learning models cannot be used as a standard for measuring teacher success in teaching HOTS. Teachers also need to know about the activities in each particular model of learning so that it can improve their HOTS. It is necessary for teachers to pay attention to these activities.

Based on some previous research, the implementation of mathematics learning on the improvement of students' HOTS can be carried out with some activities, such as involving students in non-routine problem-solving activities, providing opportunities to students for constructing their knowledge and improve their ability to analyze, evaluate, and create (Apino \& Retnawati, 2017), involving students to undergo group discussions, and communicating problem-solving results through presentations (Djidu \& Jailani, 2016b). In other words, building HOTS-oriented learning can be conducted through minimalizing teacher domination and maximizing the role of students in the learning process.

Result revealed that teachers have good knowledge on teaching HOTS to students. The teachers have mentioned some of the instructional models that contain problem-solving activities. The teachers, however, are confused about explaining the activities that can improve students' HOTS. This shows an inconsistency between the knowledge of teaching HOTS and knowledge of activities that can improve HOTS. This also indicates that the pedagogical knowledge of the teachers on how to learn and improve HOTS is still limited in term of conceptual knowledge.

HOTS-oriented mathematics learning aims at improving students' HOTS. Measuring students' HOTS in mathematics is important because it helps know whether the purpose is achieved or not. Students' HOTS can be measured through assignments and tests that are constructed based on the aspects and indicators of HOTS. Assignments can be applied by constructing rubrics, but testing can be used with various types of tests, such as multiple-choice questions or essay. Both assignment and test have specifications for measuring students' thinking skills. Multiple choice is more appropriate for measuring analyzing and evaluating skills, whereas essay is more appropriate for measuring creating skills. In addition, Watson, Collis, Callingha, and Moritz (1995) recommended open-ended questions to measure students' thinking ability followed by scoring system. The research conducted on 25 mathematics teacher candidates in Turkey came up with the findings that teachers still make mistakes in assessing students' thinking ability in making mathematical model of a given problem (Didis, Erbas, Cetinkaya, Cakiroglu, \& Alacaci, 2016). They also showed that there are still many teachers who only assess students' thinking skill based on the final outcome (only providing an assessment: true or false, good or bad, appropriate or inappropriate). Meanwhile, only a few students judge by observing the process of completion. 
Compared to the study by Didis et al. (2016), different results were found. Based on the analysis of mathematics teacher response data (see Table 5), it can be concluded that teachers have a good understanding about assessing students' thinking ability. It can be seen from teachers' responses that measuring HOTS can be carried out by constructing essay with contextual problems. Assessment focuses not only on the students' final answer but also on the process of its completion. This result is relevant to that of Altun and Akkaya (2014) that most of teachers argue that the cause of students' low ability in answering questions such as PISA is that the students are unfamiliar with them. Teachers as respondents also provided recommendations that evaluation of students' learning outcome should be carried out by using essays and contextual questions. These suggestions show that teachers already know the appropriate types of questions to measure HOTS. Some study in some countries (e.g. Altun \& Akkaya, 2014; Didis et al., 2016; Stahnke, Schueler \& Roesken-Winter, 2016) revealed that one of the determinant factors of student success in improving competence and thinking ability is the teacher competence and teachers' mastery to the learning content. In addition to that, not only mathematics pedagogical content knowledge (MPCK), but also increased mathematical content knowledge of teachers (MCK) (Blömeke \& Delaney, 2012).

The results of this study indicate that mathematics teachers have not performed well in answering HOTS problem. Most teachers do not include clear procedures in answering the questions. This is an indication that teachers' mathematical content knowledge (MCK) is still low, especially relating to their ability in solving HOTS-based questions. These results are in line with Zulkpli, Mohamed, and Abdullah (2017) who pointed out the low level of thinking ability among primary and secondary school teachers across one province in Malaysia. This condition will certainly affect students' learning achievement that is not maximal (Altun \& Akkaya, 2014; Didis et al., 2016; Stahnke et al., 2016). Besides, these results also indicate inconsistency within teachers' responses in measuring HOTS and answering to HOTS-based problems. Although teachers have revealed that assessing HOTS should not ignore the process or completion of problem-solving steps, when solving HOTS problem, most of them only write the final results and do not include the process of completion.

\section{Conclusions}

The results of this research indicate that not all teachers understand HOTS well. Teachers are still unable to distinguish HOTS from ability, skills, learning methods, learning models or learning activities. Teachers are already aware of the importance of HOTS for students. However, teachers' knowledge about the importance of HOTS still lacks good knowledge on learning and improving HOTS. Although teachers already know that students can be trained about HOTS by using some learning models (e.g. problem-based learning, project-based learning, inquiry learning, cooperative learning), teachers still confuse activities in particular models of learning. The implementation of the Bloom's Taxonomy has also not been seen in teachers' responses for measuring and assessing HOTS. Moreover, the low level of teachers' knowledge on HOTS is also caused by their low ability in solving HOTS problems. The results of this study confirm that the low level of pedagogical abilities relating to HOTS is in line with the low ability of teachers' HOTS.

Although teacher is a key to the implementation of learning process, all educational bodies have equal responsibilities for improving education in the country. Results also reveal that teachers' pedagogical knowledge and HOTS are the main concern for educational advancement. Government and education experts should find solutions to solve this problem. Therefore, conducting socialization and teacher training on improving HOTS and its implementation in mathematics learning is one of the recommendations that should be applied. In addition, learning sources such as books, access to electronic media, or other sources still need further consideration by the government, schools and education experts.

PROBLEMS

OF EDUCATION

IN THE $21^{\text {st }}$ CENTURY

Vol. 76, No. 2, 2018

227 
Heri RETNAWATI, Hasan DJIDU, KARTIANOM, Ezi APINO, Risqa D. ANAZIFA. Teachers' knowledge about higher-order thinking skills and its learning strategy

\section{PROBLEMS \\ OF EDUCATION \\ IN THE $21^{\text {st }}$ CENTURY Vol. 76, No. 2, 2018}

Different types of research can be conducted but they should base on the findings of this research. The teachers' knowledge and skills need to be described more broadly and deeply so that it can be easy to identify any side to improve. The strategy to improve the quality of teachers, especially mathematics teachers, centers on professional and pedagogical competence. Similarly, the supporting media needs to develop so that teachers can have access to them in order to improve their qualification in managing and implementing innovative teaching and learning in their respective schools.

\section{References}

Ahmad, D. (2014). Understanding the 2013 curriculum of English teaching through the teachers and policymakers' perspectives. International Journal of Enhanced Research in Educational Development, 2 (4), 6-15. Retrieved from https://pdfs.semanticscholar.org/dc45/ 58ac27a60ce91cb967 f2b3f57d8720f3791d.pdf.

Akyol, Z., \& Garrison, D. R. (2011). Understanding cognitive presence in an online and blended community of inquiry: Assessing outcomes and processes for deep approaches to learning. British Journal of Educational Technology, 42 (2), 233-250. doi:10.1111/j.1467-8535.2009.01029.x

Altun, M., \& Akkaya, R. (2014). Mathematics teachers' comments on PISA math questions and our country's students' low achievement levels. Hacettepe Üniversitesi Eğitim Fakültesi Dergisi, 29 (1), 19-34.

Anazifa, R. D. (2017). Project-based learning and problem-based learning: Are they effective to improve students' thinking skills? Jurnal Pendidikan IPA Indonesia, 6 (2), 346-355. doi:10.15294/jpii. v6i2.11100.

Anderson, O. W., \& Krathwohl, D. R. (2001). A taxonomy for learning, teaching, and assessing: A revision of Bloom's taxonomy of educational objectives. New York, NY: Longman.

Apino, E., \& Retnawati, H. (2017). Developing instructional design to improve mathematical higher order thinking skills of students. Journal of Physics: Conference Series, 812, 1-7. doi:10.1088/17426596/755/1/011001

Avargil, S., Herscovitz, O., \& Dori, Y. J. (2012). Teaching thinking skills in context-based learning: Teachers' challenges and assessment knowledge. Journal of Science Education and Technology, 21 (2), 207-225. doi:10.1007/s10956-011-9302-7.

Bartell, T. G. (2012). Learning to teach mathematics for social justice: Negotiating social justice and mathematical goals. National Council of Teachers of Mathematics, 44 (1), 129-163. Retrieved from www.nctm.org.

Bialik, M., Bogan, M., Fadel, C., \& Horvathova, M. (2015). Education for the $21^{\text {st }}$ century: What should students learn? Center for Curriculum Redesign, 3 (4), 415-420. Retrieved from www.curriculumredesign.org.

Blömeke, S., \& Delaney, S. (2012). Assessment of teacher knowledge across countries: A review of the state of research. ZDM: The International Journal of Mathematics Education, 44 (3), 223-247. doi:10.1007/s11858-012-0429-7.

Brookhart, S. M. (2010). How to assess higher-order thinking skills in your classroom. Alexandria, VA: ASCD.

Conklin, W. (2012). Higher order thinking skills to develop $21^{\text {st }}$ century learners. Huntington Beach, CA: Shell Education Publishing.

Didis, M. G., Erbas, A. K., Cetinkaya, B., Cakiroglu, E., \& Alacaci, C. (2016). Exploring prospective secondary mathematics teachers' interpretation of student thinking through analyzing students' work in modelling. Mathematics Education Research Journal, 28 (3), 349-378. doi:10.1007/s13394016-0170-6.

Djidu, H., \& Jailani. (2016a). Aktivitas pembelajaran matematika yang dapat melatih kemampuan berpikir tingkat tinggi siswa. In A. W. Kurniasih, B. E. Susilo, \& M. Kharis (Eds.), Proseding Seminar Nasional Matematika X (pp. 367-376). Semarang: Fakultas Matematika dan Ilmu Pengetahuan Alam. [Djidu, H., \& Jailani. (2016a). Activity in mathematics teaching and learning that fostering students' higher order thinking skills. In A. W. Kurniasih, B. E. Susilo, \& M. Kharis (Eds.), Mathematics National Seminar 10 th Proceeding, (pp. 367-376). Semarang: Mathematics and Social Science Faculty]. 
$\mid \begin{aligned} & \text { PROBLEMS } \\ & \text { OF EDUCATION } \\ & \text { IN THE 21 } 1^{\text {st }} \text { CENTURY } \\ & \text { Vol. 76, No. 2, } 2018\end{aligned}$

Djidu, H., \& Jailani. (2016b). Fostering students' higher-order thinking skill through problem-based learning in calculus. In Proceeding of 3rd International Conference on Research, Implementation and Education of Mathematics and Science (pp. 127-130). Yogyakarta: Faculty of Mathematics and Science-Yogyakarta State University. Retrieved from http://seminar.uny.ac.id/icriems/sites/ seminar.uny.ac.id.icriems/files/prosiding/ME-19.pdf.

Gil-Flores, J., Rodríguez-Santero, J., \& Torres-Gordillo, J.-J. (2017). Factors that explain the use of ICT in secondary-education classrooms: The role of teacher characteristics and school infrastructure. Computers in Human Behavior, 68, 441-449. doi:10.1016/j.chb.2016.11.057.

Goethals, P. L. (2013). The pursuit of higher-order thinking in the mathematics classroom. Retrieved from http://www.westpoint.edu/cfe/Literature/Goethals_13.pdf.

Hu, B. Y., Fan, X., Yang, Y., \& Neitzel, J. (2017). Chinese preschool teachers' knowledge and practice of teacher-child interactions: The mediating role of teachers' beliefs about children. Teaching and Teacher Education, 63, 137-147. doi:10.1016/j.tate.2016.12.014.

Jailani, \& Retnawati, H. (2016). The challenges of junior high school mathematic teachers in implementing the problem-based learning for improving the higher-order thinking skills. The Online Journal of Counseling and Education, 5 (3), 1-13.

Limbach, B., \& Waugh, W. (2010). Developing higher level thinking. Journal of Instructional Pedagogies, 3, 1-9. Retrieved from https://aabri.com/manuscripts/09423.pdf.

Miri, B., David, B. C., \& Uri, Z. (2007). Purposely teaching for the promotion of higher-order thinking skills: A case of critical thinking. Research in Science Education, 37 (4), 353-369. doi:10.1007/ s11165-006-9029-2.

Mokhtar, M. Z., Tarmizi, R. A., Ayub, A. F. M., \& Nawawi, M. D. H. (2013). Motivation and performance in learning calculus through problem-based learning. International Journal of Asian Social Science, 3 (9), 1999-2005. Retrieved from http://www.aessweb.com/pdf-files/Ijass-si-3(9)-1999-2005.pdf.

Moseley, D., Baumfield, V., Elliott, J., Gregson, M., Higgins, S., Miller, J., \& Newton, D. (2005). Frameworks for thinking: A handbook for teaching and learning. New York, NY: Cambridge University Press.

Orlich, D., Harder, R., Callahan, R., Trevisan, M., \& Brown, A. (2010). Teaching strategies: A guide to effective instruction. Boston, MA: Wadstworth.

Purnomo, Y. W. (2017). The complex relationship between teachers' mathematics-related beliefs and their practices in mathematics class. New Educational Review, 47 (1), 200-210. doi:10.15804/ tner.2017.47.1.16.

Quamruzzaman, A., Rodríguez, J. M. M., Heymann, J., Kaufman, J. S., \& Nandi, A. (2014). Are tuition-free primary education policies associated with lower infant and neonatal mortality in low and middle-income countries? Social Science \& Medicine, 120, 153-159. doi:10.1016/j.socscimed.2014.09.016.

Retnawati, H. (2015). Hambatan guru matematika Sekolah Menengah Pertama dalam menerapkan kurikulum baru (Teachers' of junior high school in implementation of the new curriculum). Cakrawala Pendidikan, 34(3), 390-403. [Retnawati, H. (2015). The obstacles of junior high school mathematics teachers in implementing the new curriculum. Cakrawala Pendidikan, 34 (3), 390-403].

Retnawati, H., Hadi, S., \& Nugraha, A. C. (2016). Vocational high school teachers' difficulties in implementing the assessment in curriculum 2013 in Yogyakarta Province of Indonesia. International Journal of Instruction, 9 (1), 33-48. doi:10.12973/iji.2016.914a.

Retnawati, H., Kartowagiran, B., Arlinwibowo, J., \& Sulistyaningsih, E. (2017). Why are the mathematics national examination items difficult and what is teachers' strategy to overcome it? International Journal of Instruction, 10 (3), 257-276. doi:10.12973/iji.2017.10317a.

Retnawati, H., Munadi, S., Arlinwibowo, J., Wulandari, N. F., \& Sulistyaningsih, E. (2017). Teachers' difficulties in implementing thematic teaching and learning in elementary schools. The New Educational Review, 49 (3), 201-212. doi:10.15804/tner.2017.48.2.16.

Rochani, S. (2016). Keefektifan pembelajaran matematika berbasis masalah dan penemuan terbimbing ditinjau dari hasil belajar kognitif kemampuan berpikir kreatif. Jurnal Riset Pendidikan Matematika, 3 (2), 273-283. doi:10.21831/jrpm.v3i2.5722. [Rochani, S. (2016). The effectiveness of mathematics problem-based learning and guided discovery learning viewed from the cognitive learning achievement and creative thinking skill. Jurnal Riset Pendidikan Matematika, 3 (2), 273-283. doi:10.21831/jrpm.v3i2.5722]. 
Heri RETNAWATI, Hasan DJIDU, KARTIANOM, Ezi APINO, Risqa D. ANAZIFA. Teachers' knowledge about higher-order thinking skills and its learning strategy

OF EDU

IN THE $21^{\text {st }}$ CENTURY Vol. 76, No. 2, 2018

230

Scott, L. A. (2017). 21 $1^{\text {st }}$ century skills early learning framework. Partnership for $21^{\text {st }}$ Century Skill (P21). Retrieved from http://www.p21.org/storage/documents/EarlyLearning_Framework/ P21_ELF_ Framework_Final.pdf.

Stahnke, R., Schueler, S., \& Roesken-Winter, B. (2016). Teachers' perception, interpretation, and decision-making: A systematic review of empirical mathematics education research. ZDM - Mathematics Education, 48 (1-2), 1-27. https://doi.org/10.1007/s11858-016-0775-y.

Stylianides, G. J. (2007). Investigating the guidance offered to teachers in curriculum materials: The case of proof in mathematics. International Journal of Science and Mathematics Education, 6 (1), 191-215. doi:10.1007/s10763-007-9074-y.

Sumarmo, U., \& Nishitani, I. (2010). High level mathematical thinking: Experiments with high school and under graduate students using various approaches and strategies. Bulletin of the Faculty of Education, Gunma University, 58 (9), 9-22. Retrieved from https://gair.media.gunma-u.ac.jp/ dspace/bitstream/10087/5130/1/03_Nishitani.pdf.

Thomas, A., \& Thorne, G. (2009). How to increase higher order thinking. Retrieved January 2, 2017, from http://www.readingrockets.org/article/how-increase-higher-order-thinking

Thompson, T. (2008). Mathematics teachers' interpretation of higher-order thinking in Bloom's taxonomy. International Electronic Journal of Mathematics Education, 3 (2), 1-14. Retrieved from https://www.researchgate.net/publication/26579694\%0AMathematics.

Vidergor, H. E., \& Krupnik-Gottlieb, M. (2015). High order thinking, problem based and project- based learning in blended learning environments. In H. E. Vidergor \& C. R. Harris (Eds.), Applied Practice for Educators of Gifted and Able Learners (pp. 217-232). Rotterdam: Sense Publishers. doi:10.1007/978-94-6300-004-8_11.

Watson, J. M., Collis, K. F., Callingham, R. A., \& Moritz, J. B. (1995). A model for assessing higher order thinking in statistics. Educational Research and Evaluation, 1 (3), 247-275. doi:10.1080/1380361950010303.

Zulkpli, Z., Mohamed, M., \& Abdullah, A. H. (2017). Assessing mathematics teachers' knowledge in teaching thinking skills. Sains Humanika, 9 (1-4), 83-87. doi:10.11113/sh.v9n1-4.1129.

Received: December 31, 2017

Accepted: April 08, 2018

\begin{tabular}{|ll|}
\hline \multirow{3}{*}{ Heri Retnawati } & Dr, Associate Professor, Mathematics Department, Mathematics and Science \\
& Faculty, Yogyakarta State University, Indonesia, Jl. Kolombo Karangmalang \\
& Yogyakarta 55281, Indonesia . \\
& E-mail: heri_retnawati@uny.ac.id \\
\hline \multirow{3}{*}{ Hasan Djidu } & M.Pd., Alumnae, Master Program in Mathematics Education, Graduate \\
& School of Yogyakarta State University, Jl. Kolombo Karangmalang Yogya- \\
& karta 55281, Indonesia. \\
& E-mail: hasandjidu@gmail.com \\
\hline \multirow{3}{*}{ Kartianom } & M.Pd., Alumnae, Master Program in Research and Evaluation Education, \\
& Graduate School of Yogyakarta State University, Jl. Colombo Karangmalang \\
& Yogyakarta 55281 Indonesia. \\
E-mail: kartianom@gmail.com
\end{tabular}

